\title{
English Swear Words by Indonesian Learners
}

\author{
Latif Amrullah \\ IAIN Tulungagung, Indonesia \\ Email: amrullah.latif@gmail.com
}

\begin{abstract}
Language functions to convey expression and content, either for their self or for others. Some people tend to use swear words in certain conditions and situation to show their feeling or just to express an inconvenience. In other words, swear word is closely related to anger expression. This paper examines the use of English swear words in certain simulated anger situations in order to know what kinds of swear words that the respondents use. The data were gathered through some simulated anger situations which were made by considering certain social dimensions. The respondents are the university students who were taken randomly through different classes. This study shows that certain English swear words are commonly used by the respondents and the social status of respondents governs as an important aspect.
\end{abstract}

Keywords: anger situations, swear words, university students

\section{INTRODUCTION}

There is a strong relationship between language and certain speech situation. Language is viewed as the vehicle of the thought, a system of expression that mediates the transfer of thought from one person to another (Finegan, et al, 1992: 3). Expression seems tobe the most basic notion because everyone wants to convey 
their feelings, and it is the reason why they have to create a system that makes them easily to transfer their ideas. Their expressions are closely related to certain speech situations where they have to understand it. In formal situation, they will use formal language even though it has the same basic expression like when they speak in informal situation. Thus, the ethnography of communication proposed by Hymes known as SPEAKING (Wardhaugh, 1988: 238-241) governs a very important role. Situations which can raise certain emotional expressions can give us a better view of how language is applied.

One of the informal situations we usually face is anger situation. There is no strict rule on how people should behave in that situation. Anger is the representative of unpleasant emotional accompaniments (Hilgard, 1962: 177). This is unpleasant because people never want to have such of this condition. In case that they have to face it, their reaction can be seen in terms of psychological, behavioral, and verbal expressions (Baruch et al, 2008: 4). Since language only appears in verbal reaction, this paper focuses on the use of the words, especially swearing words.

The study of swearing words has become an important aspect of linguistic research in relation with the way people behave unconsciously. There are many researches in terms of how people swear in English. The majority of the researches are on the way people use swearing words in particular condition. The use of swearing depends on the situations where it can encourage someone to deliver their swear words. Child, teen, and adult are the classification of age for those who deliver swear words (Azcona, 2003: 4-5). The research on multilingual society has ever made by Dewaele (2004) entitled Blistering Barnacles! What Language Do Multilinguals Swear In? which focused on swearing in multilingual respondents. Research revealed that morphological and morphophonemic process of Alay variation and reveals that morphological processes including affixation e.g. internal change, infixation, and core vowel change; non affixation e.g. borrowing, coinage, clipping, acronym, multiple process, reduplication and combination text and morphophonemic process e.g. loss of phoneme, addition of phoneme, simple consonant change (Nurhayati, 2015) and processes of word formation and technique understanding slang words used by Waria Tulungagung are divided into eleven processes i.e. Derivation, Multiple Process, Acronym, Borrowing, Blending, Reduplication, Synonym, Coinage, Irregular Form, Echoism, Changing of Syllable Vowel and the technique of understanding Waria sentences by removing some suffixes (Nurhayati, 2016). Other researches also pointed out swearing words as their topic, however the research on adult, especially for those who study in university, are still few.

Language as the means of conveying something that the user of the language wants to convey (Montgomery et al, 1962: 15) makes the anger expression become the obvious tool to investigate it. When people get angry, they will utter unconscious words that usually they use. It has been internalized in their mind and it can be uttered spontaneously. Swearing is widely considered as an expression of strong emotion: anger at specific others or simply deep frustration, often manifest as anger directed at the closest available target (Eckert et al, 2007: 181). The previous research was focused on the age of the respondent, but how about the respondents 
from the university students? As it has been already understood that the university students have a different way of thinking, they are supposed to be more mature on their thinking due to their age and they could decide and behave according to the social norm in accordance with their higher education social interactions than others. Therefore, this research has tended to focus on the kind of English swear words by the university students rather than the use of swear words by classifying the age of the respondents.

The purpose of this investigation is to know what kind of swear words which are used by the university students in Faculty of Cultural Sciences Universitas Gadjah Mada. It is possible for the students to utter some swear words in English which has been understood before. They can gather it from sources like action movies or anywhere. This paper also wants to examine in what situation does the swear words are occupied by the university students. It fairly depends on the respondents whether they became angry or not in that particular situation given in a questionnaire. It is interesting to note that not the entire respondents would be angry in one situation. Their unconscious mind has a great influence on it.

\section{DATA AND METHODS}

\section{Data}

Data is the fixed material for research (Mastoyo, 2007: 25). This investigation examines the type of swear words appearing in a sentence. It has been understood that when someone expresses his/her anger, he never delivers it in written. In this research, however, the respondents were requested to deliver their anger expression in the written form. The data are mostly in form of short sentences or a long sentence including additional statement of expression from the speaker.

The swear words were gathered from the responses of the situation given in the questionnaire. There are four questions that should be answered by the respondents on the question sheet. This research applied Discourse Completion Task (DCT) as the main instrument of data gathering. Then the results were analyzed in sociolinguistic approach. The questions are based on the theory of social dimensions by Holmes. Social dimensions consist of four aspects: social distance, status scale, formality scale, and functional scale (Holmes: 1995, 12). By considering this theory, the respondents will possibly deliver different degree of severity on swear words.

In collecting the data, the answers of the open questionnaires is used as the primary data. The data were gathered from the respondents of the student in Faculty of Cultural Sciences Universitas Gadjah Mada who were picked up in semi random method. As the secondary data, this research takes the sources from the library and written information in order to have enough knowledge of the background information about swear words.

\section{Methods}

The collected data then were analyzed by using sociolinguistics approach in the perspective of social dimensions based on situations given in the questionnaire (Hymes, 1974:Vii). From the questionnaire, the answers were collected and distributed into some parameters. The process of analyzing could help determining 
the variables related to the use of swear words. They were determined based on the types of swear words and the situation where the swear words were occupied.

\section{LITERATURE REVIEW}

To determine the types of swear words, this research applies the distribution table of Andrea Milwood-Hargrave 2000 in the journal Delete Expletive p. 9:

Table 1. Ranked order of words according to severity in 2000

\begin{tabular}{lll}
\hline \multicolumn{1}{c}{ WORD } & POSITION & $\mathbf{1 9 9 7}$ \\
\hline Cunt & 1 & 1 \\
Motherfucker & 2 & 2 \\
Fuck & 3 & 3 \\
Wanker & 4 & 4 \\
\hline Nigger & 5 & 11 \\
Bastard & 6 & 5 \\
\hline Prick & 7 & 7 \\
Bollocks & 8 & 6 \\
\hline Arsehole & 9 & 9 \\
Paki & 10 & 17 \\
Shag & 11 & 8 \\
\hline Whore & 12 & 13 \\
Twat & 13 & 10 \\
\hline Piss off & 14 & 12 \\
Spastic & 15 & 14 \\
Slag & 16 & 18 \\
Shit & 17 & 15 \\
\hline Dickhead & 18 & 19 \\
Pissed off & 19 & 16 \\
\hline Arse & 20 & 20 \\
\hline Bugger & 21 & 21 \\
Balls & 22 & 22 \\
Jew & 23 & 24 \\
Sodding & 24 & 23 \\
Jesus Christ & 25 & 26 \\
\hline Crap & 26 & 25 \\
Bloody & 27 & 27 \\
God & 28 & 28 \\
\hline & & \\
\hline
\end{tabular}

Those are the swear words from the research of BBC together with several institutions. At the top of list is the word related to part of woman's body. The rank of some words has changed from 1997 to 2000. It possibly happens because swear words always changes from time to time and it depends on the speaker of that language whether they still want to use it or not. However, the top four words still remain: cunt, motherfucker, fuck, wanker. 
In the English-speaking world, the most severe taboos are associated with words connected with sex, closely followed by those connected with excretion and the Christian religion. This association is a reflection of the great emphasis placed on sexual morality in their culture that traditionally developed. In other cultures the strongest taboos may be associated with religion, and in Norway, for example, some of the strongly tabooed expressions are concerned with the devil (Trudgill, 1978: 30).

The situations where the swearing words appear are in close relationship with the social dimensions of the interlocutor. Like what it has been stated above, there are four elements in social dimensions based on theory of social dimensions by Holmes. Social distance is very useful in emphasizing how well we know someone is a relevant factor in linguistic choice. It can be seen in the example whether someone calls:

1. Hi John!

2. Good morning Mr. Johnson.

\section{Scale 1.The solidarity-social distance scale $\begin{array}{ll}\text { Intimate } & \text { Distant } \\ \text { High Solidarity } & \text { Low Solidarity }\end{array}$}

If both of the speakers are intimate, it means that they have high solidarity, and if they are distant it means that they are in low solidarity. The language they used is sometimes different based on their intimacy. The choice of John and Mr. Johnson reflects consideration of this dimension. Those who are in intimate relationship are possibly delivers higher degree of swearing - though swearing does not always mean that they get angry - rather than those who are in distant relationship.

\section{Scale 2. The status scale}

\begin{tabular}{l|l} 
Superior & high status \\
Subordinate & low status
\end{tabular}

This scale points to the relevance of relative status in some linguistic choices. College students usually call their lecturer by using sir. This reflects the superiority of the lecture because he is in a high status. In other words, superiority brings great influence, including how they are respected by others from the choice of words. A person in superior status could possibly deliver swear words due to their power and they want to gain their social status. American English speaker sometimes drop [h] in particular word, for example:

"You seen our 'enry's new 'ouse yet? It's in 'alton you know."(Holmes, 1995: 6) 
This sentence reflects the low social status of the speaker considering their subordinate class. Usually, people in low class society speak more non-formal from the official language. The function is possibly to show their identity in society.

\section{Scale 3.The formality scale}

\begin{tabular}{l|l} 
Formal & High formality \\
Informal & Low formality
\end{tabular}

The scale of formality is useful in assessing the influence of the social setting or type of interaction on language choice. In a formal transaction such as one with the bank manager in his office, or at ritual services in church, the language used will be influenced by the formality of the setting. For a friendly chat, people use colloquial language. Often degrees of formality are largely determined by solidarity and status relationships. But it is not always. A very formal setting, such as law court, will influence language choice regardless of the personal relationships between the speakers.

Scale 4. The referential and affective function scales Referential

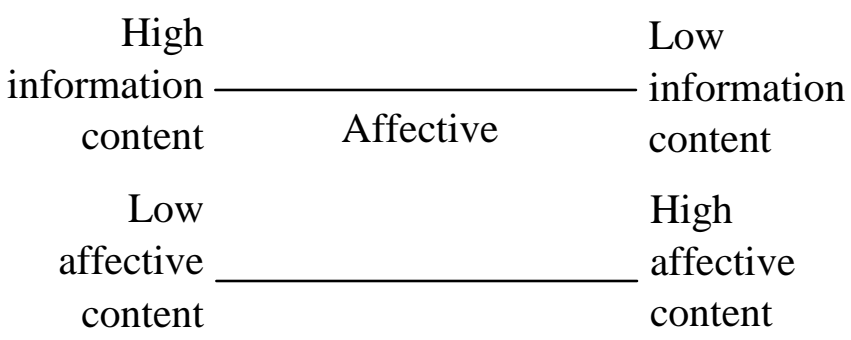

Although language serves many functions, the two definitions identified in these scales are mostly universal and basic. Language can convey objective information or a referential kind; and language can also express how someone is feeling. Girl's talk may provide a great deal of new referential information, while also clearly conveying how the speaker feels about those referred to. It is very common for utterances to work like this, though often one function will dominate. In general the more referentially oriented an interaction is, the less it tends to express the feelings of the speaker. The weather forecast in England tends to put the emphasis on information or the referential function, for example. By contrast, interactions which are more concerned with expressing feelings often have little new information to be communicated. Talk between mothers over the fence at the evening about their neighbors, for example, is more likely to be mainly affective in function, and intended to convey goodwill towards the mothers rather than important a new information. 


\section{FINDINGS AND DISCUSSION}

The table below presents the result of the type of wear words taken from the respondents. They can be either in a single word or in compound words. Some words might not appear as in the list of BBC research above. This might be the result from the influence of the using American English which is greater than British English.

Table 2. The results of Open Questionaire

\begin{tabular}{lll}
\hline Words & Frequent & Rank \\
\hline Fuck & 8 & 3 \\
Bastard & 1 & 6 \\
Shit & 4 & 17 \\
God & 5 & 28 \\
Hell & 6 & - \\
Damn & 7 & - \\
Messy & 1 & - \\
\hline
\end{tabular}

Overall, the students use the word fuck higher than others, and this word is in the third rank of severity based on BBC research. Then it is followed by other words: bastard, shit, and god. The discussion focuses on the words that available in the table 1 .

\section{a. Fuck}

This word is derived from several Germanic languages. In Middle Dutch the word means "fokken" (to thrust), Swedish "fokka" (to strike, to push, or to copulate), Norwegian "fukka" (to copulate with) and German "fucken" (also to copulate). This word appeared in English was in 1475 (Leigh and Lepine, 2005: 36-37).

This word was occupied in different form of sentence by the respondents. For example:

3. Do you realize what fucking hell you have done to me?

4. Don't tray disturb me, fuck!

The situation where the utterance appears when the respondents went to the campus, he got problem with the motorcycle. Then he arrived in the class, one of his friend mocked and made him embarrassed. In the sentence 3 , grammatically the word fuck is functioned as the adjective of noun hell. If we omit this swear word, the meaning will change because it modifies the word hell but grammatically it is still correct or acceptable. Like in a sentence was taken from Advanced Swearing Handbook page 233:

\section{Charles is talking a load of fucking crap.}

As we can see the function of fucking in the sentences 3 and 5 are the same: as the adjective. We can omit this word or we can change it with 
another adjective word, for instance. The functions of this swear words are to give an emphasis on what is being felt by the speaker and to modify the noun hell.

Sentence 4 has different form of the word fuck. This noun is especially intended to a person whom the speaker annoyed at. We can replace this word by using another swear word like the one which is listed in table 1. By using this word, it means that the speaker intends to make an association of somebody with the word he/she utters. In Indonesian sometimes we hear:

\section{Jangan ganggu aku, bangsat!}

The word fuck usually translated into Indonesia becomes bangsat as addressing name or the other way to call somebody that he/she does not like to talk to. By using this noun, the speaker will be satisfied because finally he/she can release their anger and give more verbal torture. And this word can be categorized as strong offensives words (McEnery, 2006: 30).

\section{b. Bastard}

This word only appears once in the questionnaire. The situation where this word appears is just the same as the situation of the word fuck occupied. The sentence is given below:

7. Bastard!! Do you have any grudge to me?? I have to give you a gift for your kindness!! (and I will punch).

This word is categorized as noun and its function is to give an association of the hearer that speaker is being angry. Based on McEnery (2006: 30) this word is categorized as moderate offense word, one step under strong offense word, fuck for instance. It is possible that the reason why the respondents do not use this word might be because they hear this word rarely, not as much as the previous swear word, fuck. We will see the next offense word that comes up after it.

\section{c. Shit}

Based on table 2, the next swear word after bastard is shit. This word is used 4 times by the respondents through all of the situations. This word derives from The Old English scite and the Middle Low German schite, both meaning "dung", and the Old English noun scitte, meaning "diarrhoea". The word appears in written works both as a noun and as a verb as far back as the fourteenth century (Leigh and Lepine, 2005: 254).

The respondents occupy this word in the sentences below:

8. Shit!! Don't drive anything if you don't have brain to drive it!!

9. Oh, shit..! Are you insane or you don't have a brain? 
The situation was in the street and the speaker almost had an accident because of a middle-aged woman who turned left her motorcycle without giving any sign lamp. Then she went away without any apologizing.

Those two sentences have different pattern. Sentence 8 was in the form of negative conditional sentence, while sentence 9 was in the form of question. The word shit is categorized as a noun like fuck or bastard. This word is also categorized as the mild offense word according to McEnery (2006: 30), one level under bastard. This word is also common for Indonesian's learners because in movie, song or novel contain swear words of shit very much. For example, Eddy Murphy, one of actor in America who starring film Dr. Doolittle, in one of his film Raw in 1987, he uttered shit 103 times and it was the first place, the second was fuck 92 times (Leigh and Lepine, 2005: 74).

\section{d. God}

The last swear words to be discussed is god as a part of the table 1. In the questionnaire, there are several forms of this word:

\section{Oh my God!! What a wonderful day I have! 11. Oh my God!! Shit!}

The situation when both sentences appear is just same. When he planned to do the homework, suddenly the electricity was off and it on again in the midnight. Then he did the job until 3 a.m. in the morning. It was a hard rain before he left his house. In campus, the lecture did not come and the homework did not need to be submitted. It can be said, supposedly, that it was a bad day of the respondent.

McEnery categorized god as religious oath used for emphasis (2006: $30)$. Because this word related to religion, so this word is considered as very mild offense word. From the two sentences above, it is interesting to pay attention on the next statement. In sentence 10, the speaker wanted to express his feeling by using expressive function. It does not mean that the day is beautiful; however it is used to say the bad day by using opposite statement. And the sentence 11 obviously cursed the day, not the lecturer or the electricity. In Indonesian, this word is translated as tuhan, and Indonesia very often say this word usually as surprising or astonishment.

Besides the type of swear words, this research also wanted to answer about in what situation does the swear words are occupied. Actually there are more swear words than below, but this research only focuses on the words occupied by respondents that available in the table 1 . Based on social dimensions above, the results of each situation from questionnaire sheet are given below: 
Table 3. The appearance of swear word.

\begin{tabular}{lll}
\hline Situation & Social dimension & Swearing words (total) \\
\hline I & Solidarity scale: distant & Shit (2), fuck (1) \\
II & Solidarity scale: distant & Fuck (3), bastard (1) \\
IV & Status scale: superior & Fuck (2), shit (1) \\
\hline
\end{tabular}

Situation I: when the respondent was driving a motorcycle, suddenly in front of him there was a middle-aged woman who turned left without turning on the sign lamp. Then she went away without asking apology. In this case, the respondent does not have a close relationship with the woman. Consider that both of them have never met before. We see that the word shit and fuck are the only words that available in the table 3. It is assumed assume that if the respondent has close relationship with the woman, there is a possibility that he will not use that kind of words. Because they do not have high solidarity and perhaps their status is the same, the choice of words greatly depends on the person whether he/she wants to swear. They tend to use swear in accident because the situation is not formal.

Situation II: when the respondent had been ready to go to the campus, the gasoline was empty, while actually he had been late. Arriving in the class, one of his friend mocked him up, so the lecture laughed. Because of that person, the respondent wanted to take revenge in outside the class. From this situation is clearly seen that there is no close relationship between the speaker and the hearer. It is just the same as the situation I above, though logically situation II has more close relation between both of them. It is possible that the speaker has already known the hearer before, but they were not a close friend, just a common friend of the same class. However, the word fuck and bastard become the word that they used; it was higher than the first situation. It may happen because the speaker feels embarrassed as somebody mocked him in public and the effects of this incident is long enough, at least until the end of their study. It differs from situation I where the effect only happens at that time, no more.

Situation IV: as a chief committee of Indonesian Independence Day in his village, the respondent has responsibility for all over the activities. In the art performance night, the other comrades did not help for the preparation and after it they did not help for cleaning the place. It made the performance did not go well. From this point, the respondent annoyed with his comrades. In this situation, the respondent is positioned as having higher position than the other members in that committee. The word fuck appears two times and shit only one. It indicates that because the respondent has higher position than the other, and has bigger responsibility, he swears by using high severity word. He is in superior position and his status enables the respondent to do so. Even if the respondent has close relation with the comrades, he/she will swear by using this word because of his big responsibility and status.

From the discussion of sociolinguistics above, we can observe that people who has higher position tends to swear more severe than people who has no higher position. It may happen because of the responsibility of that person. After that the 
swear words appear in solidarity scale where both the speaker and the respondent has no relationship at all.

\section{CONCLUSION}

This research finally comes up with two conclusions based on the discussion above. First, the most severe words used by Indonesian are fuck, then bastard, shit, god. They never use the most severe words based in table 1: cunt which is uncommon for Indonesian learners. Beside as the most severe, these swear words are also the most occupied word by the respondents, more than god or shit. These words are very common for Indonesian students, for example as what Eddy Murphy did in his film by swearing much.

Second, people who are in higher position, tends to swear more severe than people who just have no close relationship with other. It may happen due to the responsibility of that people. It is clear that the social dimensions have an influence toward the occupying of swear words. Each of social dimensions, in this case solidarity scale and status scale, has different atmosphere for swearing.

\section{REFERENCES}

Allan, Keith and Kate Burridge. (2007). Forbidden Words: Taboo and Censoring of Language. Cambridge: Cambridge University Press.

Azcona, Rosemary Beam de. (2003). Aging of the Foul Mouth: The Ultimate Equalizer. Unpublished.

Baruch, Rhoda., Edith H. Grotberg, and Suzane Stutman. (2008). Creative Anger: Putting That Powerful Emotion to Good Use. London: Preager.

Dewaele, J-M. (2004). Blistering barnacles! What language do multilinguals swear in?. Estudios de Sociolinguistica. London: Birkbeck University of London.

Eckert, Penelope and Sally McConnel-Ginet. (2007). Language and Gender. Cambridge: Cambridge University Press.

Finegan, Edward, et al. (1992). Language: Its Structure and Use. Sydney: Harcourt Brace Jovanovich.

Hargrave, Andrea Milwood. (2000). Delete Expletive: Research of Advertising Standards Authority, British Broadcasting Corporation, Broadcasting Standards Commission and the Independent Television Commission.

Hilgard, Ernest R. (1962). Introduction to Psychology. $3^{\text {rd }}$ ed. New York: Harcourt Brace \& World Inc.

Holmes, Janet. (1995). An Introduction to Sociolinguistics. London: Longman.

Hymes, Dell. (1974). Foundation in Sociolinguistics: An Ethnographic Approach. Philadelphia: University of Pennsylvania Press.

Kesuma, Tri Mastoyo Jati. (2007). Pengantar (Metode) Penelitian Bahasa. Yogyakarta: Carasvatibooks.

Leigh, Mark and Mike Lepine. (2005). Advanced Swearing Handbook. West Sussex: Summersdale.

McEnery, Tony. (2006). Swearing in English: Bad Language, Purity and Power From 1586 To The Present. London: Routledge. 
Montgomery, Robert L Jr. and William O.S. Sutherlan Jr. (1962). Language and Ideas. Boston: Little, Brown Company.

Nurhayati, Dwi Astuti Wahyu.(2015). Morphological Process and Morphophonemic Process of Allay Variation. Lingua. Vol.12.No.1, March 2015. 61-72.

Nurhayati, Dwi Astuti Wahyu. (2016). Word Formation Procesess and a Technique in Understanding Waria Slang Tulungagung. EFL Journal. Vol.1. No.1. Maret 2016.

Trudgill, Peter. (1978). Sociolinguistics an Introduction. Middlesex: Penguin Books. Wardhaugh, Ronald. (1988). An Introduction to Sociolinguistics. New York: Basil Blackwell. 